\title{
To Blend or Not to Blend? A Framework for Nationwide Landsat-MODIS Data Selection for Crop Yield Prediction
}

\author{
Yang Chen ${ }^{1, *(\mathbb{D}}$, Tim R. McVicar ${ }^{2}{ }^{(}$, , Randall J. Donohue ${ }^{2}$, Nikhil Garg ${ }^{1}$, François Waldner ${ }^{3}{ }^{(}$, \\ Noboru Ota ${ }^{4}$, Lingtao $\mathrm{Li}^{2}$ and Roger Lawes ${ }^{4}$ \\ 1 CSIRO Data61, Goods Shed North, 34 Village St, Docklands, VIC 3008, Australia; \\ Nikhil.Garg@data61.csiro.au \\ 2 CSIRO Land and Water, GPO Box 1700, Canberra, ACT 2061, Australia; Tim.Mcvicar@csiro.au (T.R.M.); \\ Randall.Donohue@csiro.au (R.J.D.); Lingtao.Li@csiro.au (L.L.) \\ 3 CSIRO Agriculture and Food, 306 Carmody Rd, St Lucia, QLD 4067, Australia; Franz.Waldner@csiro.au \\ 4 CSIRO Agriculture and Food, 147 Underwood Ave, Floreat, WA 6014, Australia; \\ Noboru.Ota@csiro.au (N.O.); Roger.Lawes@csiro.au (R.L.) \\ * Correspondence: y.chen@csiro.au; Tel.: +61-9518-5990
}

Received: 1 May 2020; Accepted: 19 May 2020; Published: 21 May 2020

\begin{abstract}
The onus for monitoring crop growth from space is its ability to be applied anytime and anywhere, to produce crop yield estimates that are consistent at both the subfield scale for farming management strategies and the country level for national crop yield assessment. Historically, the requirements for satellites to successfully monitor crop growth and yield differed depending on the extent of the area being monitored. Diverging imaging capabilities can be reconciled by blending images from high-temporal-frequency (HTF) and high-spatial-resolution (HSR) sensors to produce images that possess both HTF and HSR characteristics across large areas. We evaluated the relative performance of Moderate Resolution Imaging Spectroradiometer (MODIS), Landsat, and blended imagery for crop yield estimates (2009-2015) using a carbon-turnover yield model deployed across the Australian cropping area. Based on the fraction of missing Landsat observations, we further developed a parsimonious framework to inform when and where blending is beneficial for nationwide crop yield prediction at a finer scale (i.e., the $25-\mathrm{m}$ pixel resolution). Landsat provided the best yield predictions when no observations were missing, which occurred in $17 \%$ of the cropping area of Australia. Blending was preferred when $<42 \%$ of Landsat observations were missing, which occurred in $33 \%$ of the cropping area of Australia. MODIS produced a lower prediction error when $\geq 42 \%$ of the Landsat images were missing ( $50 \%$ of the cropping area). By identifying when and where blending outperforms predictions from either Landsat or MODIS, the proposed framework enables more accurate monitoring of biophysical processes and yields, while keeping computational costs low.
\end{abstract}

Keywords: MODIS; Landsat; data blending; crop yield prediction; gap-filling

\section{Introduction}

The world's human population is projected to increase by more than $35 \%$ by 2050 [1]. To contribute to improved global food security, the next generation of crop models and agricultural decision support tools needs to efficiently and consistently operate across various scales [2]. Accurate nationwide crop yield forecasts may ensure food security to the citizens. More accurate crop yield prediction at the subfield scale can provide farmers with more detailed information for guiding, within the growing season, in-field variable rate applications of fertilizer, herbicides, and pesticides. An efficient 
approach to monitor crop growth uses satellite observations providing repeated synoptic regional assessments [3-6]. High-temporal-frequency (HTF) observations are required to accurately track crop development [7] and predict yield [8], and high-spatial-resolution (HSR) observations are necessary to capture within-field heterogeneity [9].

There is a trade-off between temporal frequency and spatial resolution [10-12] as no single sensor can regularly image vast areas of the Earth used for nation-wide dryland cropping at a high spatial resolution. Commercial options of products combine HTF and HSR images achieved by increasing the number of satellites in orbit, such as PlanetScope; however, such commercial options are not affordable for national-scale monitoring, especially in a country as large as Australia $\left(7.7\right.$ million $\left.\mathrm{km}^{2}\right)$, with the southern Australian cereal-based agricultural system notionally covering 530,000 km² [13]. The Moderate Resolution Imaging Spectroradiometer (MODIS) provides complete coverage of the globe every day at a 250-m spatial resolution from red and near-infrared bands. This resolution constrains the capacity of describing cropping systems, crop growth, and field heterogeneities, especially when fields are small-to-moderate sized and landscapes are fragmented [14,15]. Sensors with higher spatial resolution, such as Sentinel-2 or Landsat, are more suitable for these smaller fields/management units, but their lower temporal frequencies limit their ability to capture rapidly evolving crop processes, especially when factoring in the potential clouds [16]. Lobell et al. [17] used valid Landsat observations (cloud cover $<10 \%$ ) during the growing season to generate optical-based vegetation indices (Vis) and then fitted a multilinear regression between these VIs and a large number of Agricultural Production Systems Simulator (APSIM) simulations for yield prediction. In a country like Australia, most of the arable non-irrigated land grows winter wheat, barley, oats, and canola, and their growth depends on the in-season rainfall; therefore, totally cloud-free time-series observations for their entire growing season are infrequent.

To overcome these challenges, various methods for spatial filtering [18], temporal gap-filling [19-21], and data fusion [22-24] were devised with a varying degree of success. As spatial filtering and temporal gap-filling disregard the spatial and temporal correlation of a pixel, they are highly sensitive to the choice of size/length of the spatial/temporal window [20,25]. Data fusion techniques, on which this article focuses, were shown to improve the temporal resolution of fine-spatial-resolution data by blending observations from sensors with different spatial and temporal characteristics. Prominent examples are the Spatial and Temporal Adaptive Reflectance Fusion Model (STARFM; Gao et al. [12]) and the Enhanced STARFM (ESTARFM; Zhu et al. [11]). However, blending is no "silver bullet", as it often introduces unforeseen spatial and temporal variances [10]. Therefore, it is critical to systematically evaluate the benefits of blending and identify where and when blending helps to improve monitoring.

Blending satellite data with complementary frequency and spatial resolution characteristics, such as MODIS (herein considered as an HTF and low-spatial-resolution (LSR) sensor) and Landsat (herein considered as a low-temporal-frequency (LTF) and HSR sensor), provides a solution of synthetic imagery that is both HTF and HSR [26]. Current literature such as Dong et al. [27] found that using Landsat images provides a higher crop yield prediction accuracy for field scales over MODIS images, and a further improvement can be achieved by combining Landsat and MODIS (L-M) blended data with the incomplete Landsat series. To date, the utility of blended output is not yet tested for regional and national crop yield mapping [28-35] (Table 1); this study fills that niche.

This study quantifies and evaluates the benefits of blending satellite data of different temporal frequencies and spatial resolutions for crop yield prediction. The specific objectives of this study are to (i) estimate yields using MODIS, Landsat, and L-M blended data and then compare the yield prediction at both pixel and field scales, (ii) identify the fraction of missing Landsat data during a growing season considering the 16-day acquisition cycle to determine a threshold where the blended data can improve the prediction, and (iii) quantify the improvements in the yield prediction accuracy based on the threshold. 
Table 1. Review of studies that used data fusion approaches to estimate crop yields and other variables highly related to crop yield (e.g., growing season evapotranspiration and crop phenology). Records are sorted chronologically then alphabetically. When more than one site is reported in a single paper, these are identified with an (A) and (B) in the relevant columns as required. $R^{2}$ : the coefficient of determination; RMSE: root-mean-square error; $M A E$ : mean absolute error; RMAE: relative MAE; NR: not reported. In Australia, dryland agriculture is practiced across the region known colloquially as the "wheatbelt". STARFM-Spatial and Temporal Adaptive Reflectance Fusion Model; ESTARFM—enhanced STARFM; MODIS—Moderate Resolution Imaging Spectroradiometer; NIR—near infrared; US-United States; NE-New England; NASA—National Aeronautics and Space Administration; L-M-Landsat/MODIS blend; HTF-high temporal frequency; HSR—high spatial resolution.

\begin{tabular}{|c|c|c|c|c|c|c|}
\hline Reference & Blending Algorithm & $\begin{array}{c}\text { Remote Sensing (RS) } \\
\text { Data }\end{array}$ & Crop Type & $\begin{array}{c}\text { RS Variables (e.g., Vegetation } \\
\text { Index (VI))/Study } \\
\text { Period/Region/Study Area } \\
\left(\mathrm{km}^{2}\right)\end{array}$ & $\begin{array}{l}\text { RS-Bases Model to } \\
\text { Estimate Crop Yields }\end{array}$ & Key Results and Accuracy \\
\hline [28] & $\begin{array}{c}\text { Spatial and Temporal } \\
\text { Adaptive Vegetation } \\
\text { Index Fusion Model } \\
\text { (STAVIF) }\end{array}$ & $\begin{array}{l}\text { MODIS and Huanjing } \\
\text { Satellite } \\
\text { Charge-Coupled } \\
\text { Device (HJ-CCD) }\end{array}$ & Winter wheat & $\begin{array}{l}\text { Normalized difference } \\
\text { vegetation index } \\
\text { (NDVI)/2008-2009/Yucheng, } \\
\text { Shandong, China/NR }\end{array}$ & Empirical model & $\begin{array}{c}\text { The estimated winter wheat biomass correlated } \\
\text { well with observed biomass }\left(R^{2}=0.88 \text { and } M A E\right. \\
=17.2 \mathrm{~kg} / \mathrm{ha} \text { ) using the blended data. }\end{array}$ \\
\hline [29] & STARFM & $\begin{array}{l}\text { Satellite for } \\
\text { Observation of Earth } \\
\text { (SPOT) } 5 \text { and HJ-1 } \\
\text { CCD }\end{array}$ & Winter wheat & $\begin{array}{c}\text { NDVI and ratio vegetation } \\
\text { index (RVI) } \\
\text { (NIR/Red)/2008-2009/(A) } \\
\text { Rugao county, Jiangsu, and (B) } \\
\text { Anyang county, Henan, } \\
\text { China/(A) } 0.36 \mathrm{~km}^{2} \text { and (B) } \\
0.30 \mathrm{~km}^{2}\end{array}$ & Empirical model & $\begin{array}{c}\text { (A) The accumulated NDVI derived from the } \\
\text { blended data gave a higher prediction accuracy } \\
\left(R^{2}=0.67 \text { and } R M S E=0.36 \mathrm{t} / \mathrm{ha} \text { ) for wheat yield }\right. \\
\text { at Rugao. } \\
\text { (B) The accumulated RVI derived from the } \\
\text { blended data produced a higher prediction } \\
\text { accuracy }\left(R^{2}=0.65 \text { and } R M S E=0.36 \mathrm{t} / \mathrm{ha}\right) \text { for } \\
\text { wheat yield at Anyang. }\end{array}$ \\
\hline [31] & STARFM & MODIS and Landsat & Corn and soybean & $\begin{array}{c}\text { Evapotranspiration } \\
\text { (ET)/2013/Central Valley, } \\
\text { California, the US/(A) } 0.34 \mathrm{~km}^{2} \\
\text { and (B) } 0.21 \mathrm{~km}^{2}\end{array}$ & Empirical model & $\begin{array}{l}\text { The daily ET derived from the blended data } \\
\text { produced the RMAE of } 19 \% \text { with the observed ET } \\
\text { (mm/day). The spatial pattern of cumulative ET } \\
\text { corresponded to the measured yield. }\end{array}$ \\
\hline [27] & ESTARFM & MODIS and Landsat & Winter wheat & $\begin{array}{l}\text { Green leaf area index } \\
\text { (GLAI)/2013/Southwestern } \\
\text { Ontario, Canada/225 km² }\end{array}$ & Semi-empirical model & $\begin{array}{l}\text { The Landsat GLAI (GLAIL) produced an } R^{2} \text { of } \\
0.77 \text { and RMSE of } 2.31 \mathrm{t} / \mathrm{ha} \text {; the blended GLAI } \\
\text { (GLAIF) resulted in an } R^{2} \text { of } 0.71 \text { and RMSE of } \\
1.93 \mathrm{t} / \mathrm{ha} \text {; the combination of GLAIL and GLAIF } \\
\text { led to further improvements }\left(R^{2}=0.76 \text { and }\right. \\
\text { RMSE }=1.76 \mathrm{t} / \mathrm{ha}) .\end{array}$ \\
\hline [30] & ESTARFM & MODIS and Landsat & Corn and soybean & $\begin{array}{l}\text { NDVI/2001-2014/Central Iowa, } \\
\text { the US/200 km² }\end{array}$ & Empirical model & $\begin{array}{l}\text { A linear correlation }\left(R^{2}=0.83\right) \text { between remotely } \\
\text { sensed green-up dates and the emergence dates } \\
\text { reported by NASA. }\end{array}$ \\
\hline [32] & STARFM & MODIS and Landsat & Maize & $\begin{array}{l}\text { ET/2010-2014/Mead, NE, the } \\
\text { US/(A) } 0.49 \mathrm{~km}^{2} \text {, (B) } 0.52 \mathrm{~km}^{2} \\
\text { and (C) } 0.65 \mathrm{~km}^{2}\end{array}$ & Empirical model & $\begin{array}{l}\text { The county-level correlation between observed } \\
\text { and predicted maize yields improved from } 0.47 \text { to } \\
0.93 \text { when aligning the ratio of actual-to-reference } \\
\text { ET by emergence date rather than calendar date. }\end{array}$ \\
\hline
\end{tabular}


Table 1. Cont.

\begin{tabular}{|c|c|c|c|c|c|c|}
\hline Reference & Blending Algorithm & $\begin{array}{l}\text { Remote Sensing (RS) } \\
\text { Data }\end{array}$ & Crop Type & $\begin{array}{c}\text { RS Variables (e.g., Vegetation } \\
\text { Index (VI))/Study } \\
\text { Period/Region/Study Area } \\
\left(\mathrm{km}^{2}\right)\end{array}$ & $\begin{array}{l}\text { RS-Bases Model to } \\
\text { Estimate Crop Yields }\end{array}$ & Key Results and Accuracy \\
\hline [33] & STARFM & MODIS and Landsat & Corn and soybean & $\begin{array}{l}\text { NDVI and enhanced vegetation } \\
\text { index (EVI2)/2001-2015/Central } \\
\text { Iowa, the US/200 } \mathrm{km}^{2}\end{array}$ & Empirical model & $\begin{array}{l}\text { Maximum EVI2 derived from L-M blended data } \\
\text { produced the highest } R^{2}(0.59 \text { and } 0.39) \text { and the } \\
\text { lowest } R M A E(6.1 \% \text { and } 9.1 \%) \text { for corn and } \\
\text { soybeans, respectively, compared with using } \\
\text { single data source alone. }\end{array}$ \\
\hline [34] & $\begin{array}{l}\text { A pixel-wise linear } \\
\text { regression model }\end{array}$ & MODIS and Landsat & $\begin{array}{l}\text { Alfalfa, barley, maize, } \\
\text { peas, durum wheat, } \\
\text { spring wheat, and } \\
\text { winter wheat }\end{array}$ & $\begin{array}{l}\text { NDVI/2008-2015/Montana, the } \\
\text { US/4.13 million ha }\end{array}$ & Semi-empirical model & $\begin{array}{l}\text { A correlation of } 0.96\left(R^{2}=0.92 \text {, relative } R M S E=\right. \\
37.0 \%, p<0.05) \text { resulted when comparing the } \\
\text { yield prediction using the blended data with the } \\
\text { reported crop production data on county level. }\end{array}$ \\
\hline [26] & ESTARFM & MODIS and Landsat & $\begin{array}{l}\text { Cotton and winter } \\
\text { wheat }\end{array}$ & $\begin{array}{l}\text { NDVI/2004-2014/Fergana } \\
\text { Valley, Uzbekistan/NR }\end{array}$ & Semi-empirical model & $\begin{array}{l}\text { The } R^{2} \text { is } 0.56(R M S E=0.63 \mathrm{t} / \mathrm{ha}) \text { for wheat, and } \\
0.631(R M S E=0.48 \mathrm{t} / \mathrm{ha}) \text { for cotton, respectively. }\end{array}$ \\
\hline [35] & STARFM & MODIS and Landsat & Corn and soybean & $\begin{array}{l}\text { GLAI/2015/Southwestern } \\
\text { Ontario, Canada/112 km² }\end{array}$ & Semi-empirical model & $\begin{array}{c}\text { The RMSE of yield prediction is } 1.46 \mathrm{t} / \mathrm{ha}\left(R^{2}=\right. \\
0.56) \text { for corn and } 0.86 \mathrm{t} / \text { ha }\left(R^{2}=0.54\right) \text { for soybean } \\
\text { using the blended data. }\end{array}$ \\
\hline This study & ESTARFM & MODIS and Landsat & $\begin{array}{l}\text { Wheat, barley, and } \\
\text { canola }\end{array}$ & $\begin{array}{l}\text { NDVI/2009-2015/Australian } \\
\text { wheatbelt/ 53 million ha }\end{array}$ & Semi-empirical model & $\begin{array}{l}\text { Comparing HTF, HSR data against the blended } \\
\text { data for yield prediction at various scales. } \\
\text { Identifying a threshold to determine when and } \\
\text { where the blended data can improve in the } \\
\text { nationwide yield prediction at the } 25 \text {-m pixel } \\
\text { resolution when using multiple spatio-temporal } \\
\text { resolution images. Quantifying and evaluating } \\
\text { the improvements in the yield prediction } \\
\text { accuracy at various scales based on the threshold. }\end{array}$ \\
\hline
\end{tabular}




\section{Study Area and Data}

\subsection{Study Area}

The southern Australian agricultural system is dominated by dryland agriculture where cereals (e.g., wheat, barley, and oats), oilseeds (e.g., canola), and legumes (e.g., lupins, chickpeas, field peas, and soybeans) are planted, often in rotation with annual pastures and fallows. Australian wheatbelt (Figure 1) spans an extremely variable agroecological environment with respect to the climate across the continent, leading to the high spatial variability in Australian grain production. The precipitation varies enormously across the country (Figure S1, Supplementary Materials); winter (June-August) precipitations are dominant in Western Australia and South Australia, while summer (December-February) precipitations are dominant in Queensland and northern New South Wales. In southern New South Wales and Victoria, total precipitation is more uniformly distributed throughout the seasons where summer precipitation is more intense indicating that winter precipitation is more frequent [36]. Long-term average monthly accumulated precipitation records strongly correlate with the average number of rainy days (Figure S1, Supplementary Materials).

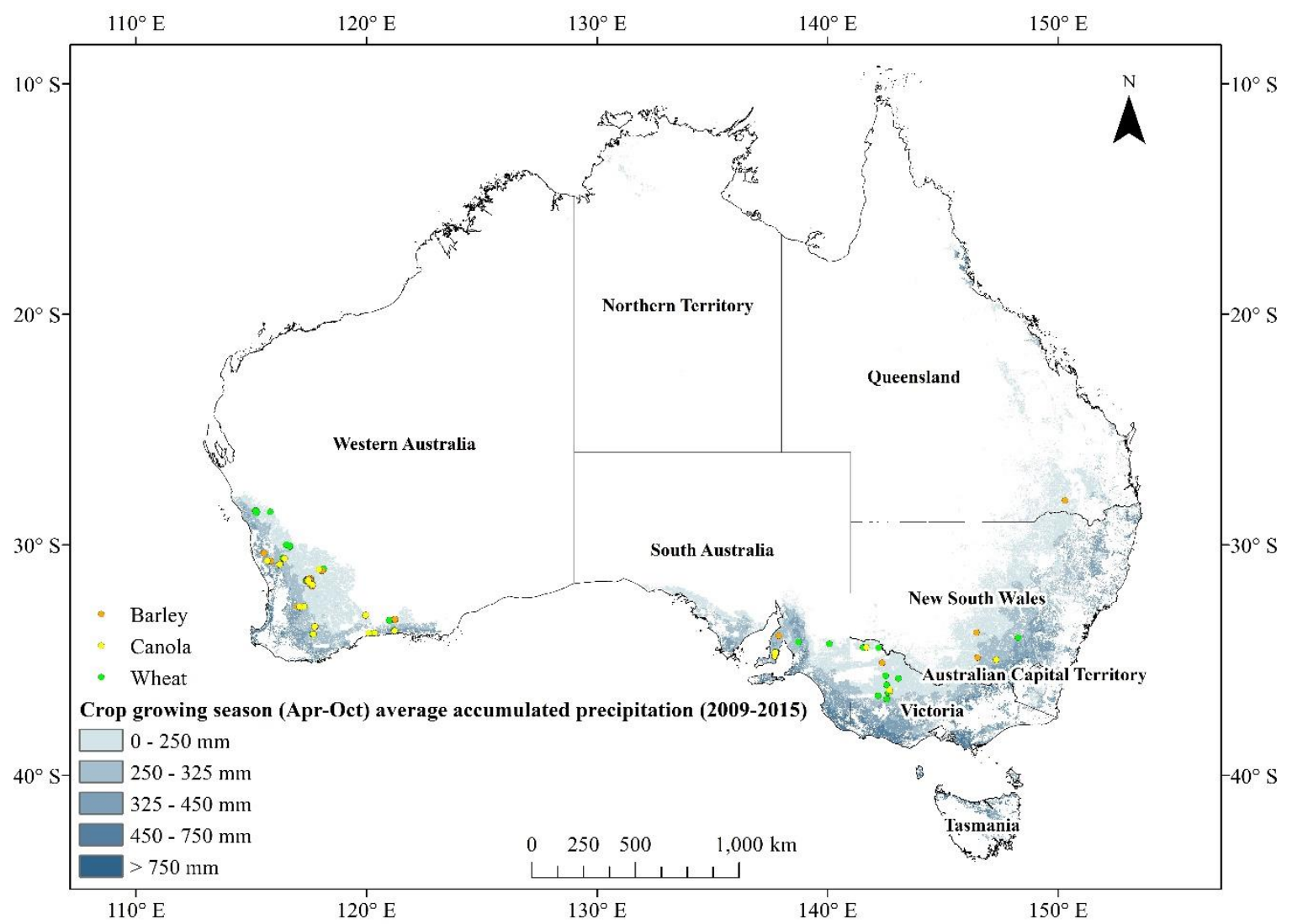

Figure 1. Study sites and the crop growing season (April-October) average accumulated precipitation (mm for the years 2009-2015) across the Australian wheatbelt ( 53 million ha) [13]. The precipitation data are sourced from Jeffrey et al. [37].

\subsection{Data}

\subsubsection{Satellite Images and L-M Blended Data}

Time series of Landsat-5 Thematic Mapper (TM), Landsat-7 Enhanced Thematic Mapper (ETM)+, and Landsat-8 Operational Land Imager (OLI) and Thermal Infrared Sensor (TIRS) standardized surface reflectance data are sourced from Geoscience Australia (http://geoscienceaustralia.github.io/ digitalearthau/index.html), which contains 239 scenes covering the Australian wheatbelt across seven 
years (2009-2015). These images are nadir-corrected, adjusted for bidirectional reflectance distribution function, and topographically corrected followed by Li et al.'s methods [38], resulting in a 25-m pixel resolution. This is as, in Geoscience Australia's processing stream, they oversample the Landsat imagery to $25 \mathrm{~m}$ to allow easier integration with other remote sensing data sources. Time series of normalized difference vegetation index (NDVI) are then computed using the red and near-infrared bands [39]. The 16-day composite of MODIS NDVI (MOD13Q1 v006) data are used due to the low clouds, low view angle, and the highest NDVI value at 250-m spatial resolution. The MODIS data are sourced from United States Geological Survey for the corresponding periods and area (16 tiles) and are then downscaled to $25 \mathrm{~m}$ by $25 \mathrm{~m}$ spatial resolution using nearest neighbor interpolation [40] for input to the blending algorithm and for consistency to enable further analysis.

The inter-annual variability of precipitation (Figure $2 b$ ) illustrates that the probability of rain days is higher during June-August (i.e., tillering to flowering phase), which is a critical period for crop yield prediction [41,42]. Figure $2 \mathrm{~b}$ also shows the value of 0.58 in July at the 75th quartile, which indicates that the probability of cloud-free Landsat images could be lower than $42 \%$ in most areas. Here, $75 \%$ of field-scale Landsat missing data occur during the growing season (i.e., 113-289 days of the year (DOY)), and only $25 \%$ of the Landsat data are complete sequences (Figure 3 ).
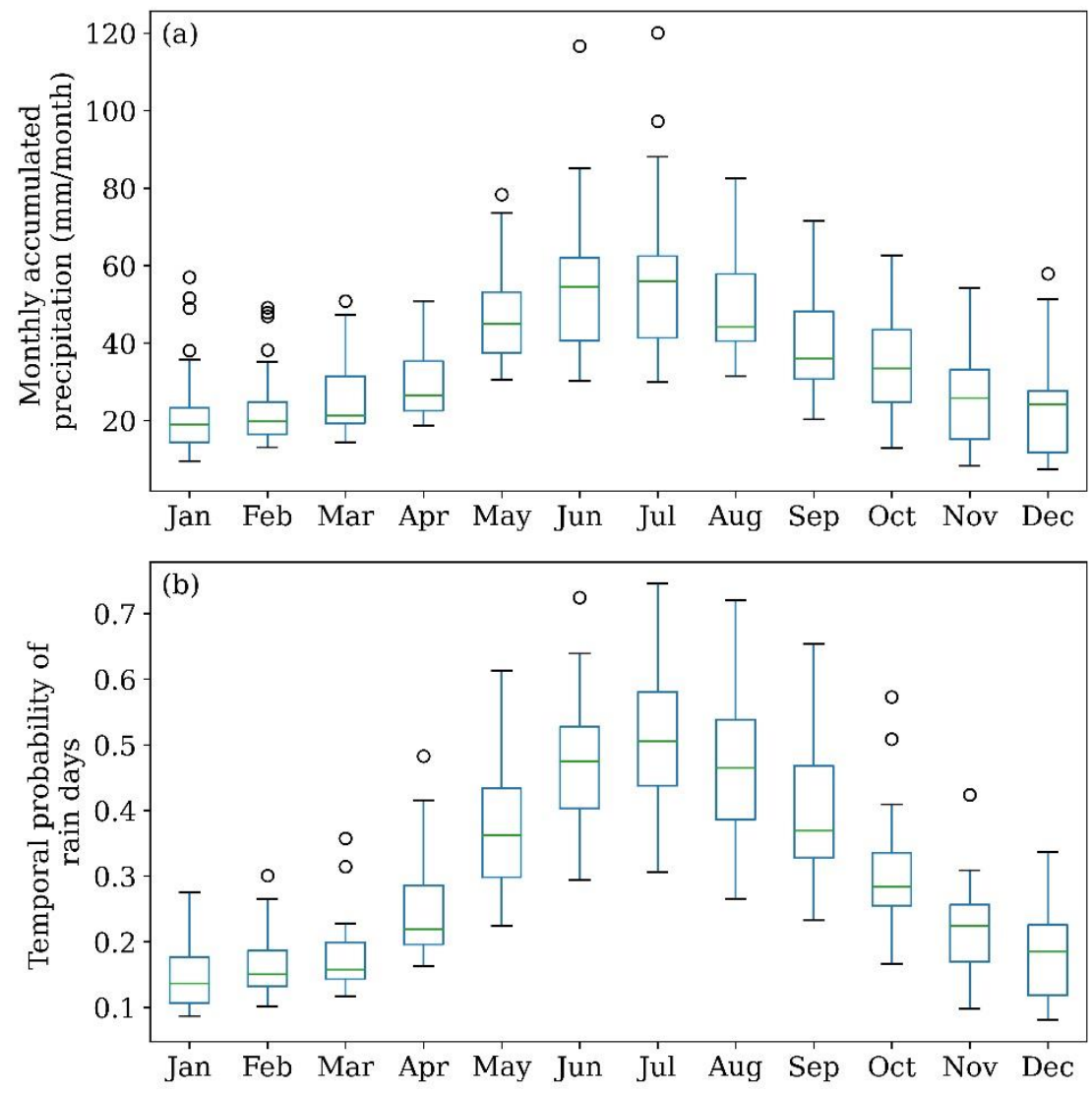

Figure 2. Box-whisker plots of 1901 to 2018 averaged (a) monthly accumulated precipitation (mm/month) across the Australian wheatbelt (see Figure 1) and (b) monthly probability of rain days (bottom). For both parts, the horizontal line represents the median of the data, the box spans from 25th to 75th quartiles of the data, and the circles past the end of the whiskers are outliers, while the rain day threshold is $0 \mathrm{~mm} /$ day. 


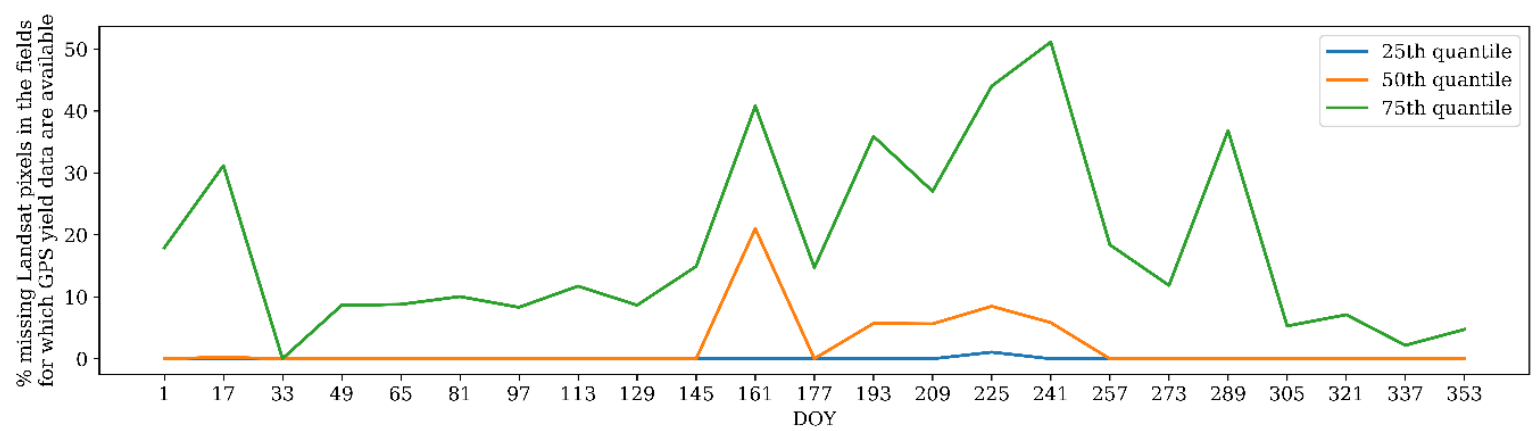

Figure 3. The quantile of Landsat missing pixels in the fields for which observed yield data are available (2009 to 2015).

To blend MODIS and Landsat NDVI data and create the 16-day time series of gap-filled Landsat-like images, we applied ESTARFM [11], which is superior when the spatial variance is dominant [10]. We follow Jarihani et al.'s [22] recommendation to "index then blend", as it yields more accurate results and provides higher computational efficiency than the "blend then index" approach. Figure S2 (Supplementary Materials) illustrates the blending process and the resulting Landsat-like image. As a result of data blending, each pixel is described by 22 observations across the calendar year. For more details about ESTARFM see [11,43].

\subsubsection{Yield Data}

Australia's major dryland crops are selected for yield estimates and validation, including 35 fields of canola, 123 fields of wheat, and 52 fields of barley (Table S1, Supplementary Materials). The average area of these fields is $\sim 112$ ha with a standard deviation of $\sim 69$ ha. Using various yield monitoring systems mounted on grain harvesters operated by farmers, these observed data were collected at these sites across the country from 2009 to 2015 (Figure 1). The data obtained by these commercially available yield monitors were used to construct a yield data image at 5-m resolution [44], which was upscaled to $25 \mathrm{~m}$ and $250 \mathrm{~m}$ to match the Landsat and MODIS resolutions, respectively.

\subsubsection{Climate Data}

Climate data were sourced from Science Information for Land Owners (SILO) which provides nationwide meteorological variables (e.g., maximum and minimum air temperature, and precipitation) at daily temporal frequencies by interpolating observations made by the Australian Bureau of Meteorology onto a $0.05^{\circ}$ by $0.05^{\circ}$ grid [37].

\section{Methods}

\subsection{Yield Prediction}

We use a semi-empirical model [C-Crop; 6]) because of its low data requirements for calibration across large areas. C-Crop correlates actual grain weight ( $\mathrm{t} / \mathrm{ha}$ ) to end-of-season above-ground plant carbon mass $(C)$, and the estimation of $C$ is based on biophysical principles of plant photosynthesis [6]. $C_{i}$ is estimated using the carbon mass $\left(C_{i-1}\right)$ from the previous time step and the current period's allocated net assimilation flux $N_{i}\left(\mathrm{gCm}^{-2}\right)$ minus the dead biomass that enters the litter store, and $i$ (1-22) is the model time step (every 16 days in a calendar year).

$$
C_{i}=(1-\rho)\left(C_{i-1}+N_{i}\right)
$$

where $\rho$ (periods $^{-1}$ ) is the reciprocal of carbon longevity (i.e., the turn-over rate of plant live carbon into senesced tissue per time step $i$ ). 


\subsubsection{Net Primary Productivity}

Net primary productivity (NPP) is the rate of carbon assimilation from atmospheric $\mathrm{CO}_{2}$ to organic material (biomass) for a given area while accounting for the energy loss due to autotrophic respiration [6,45].

$$
N_{i}=0.75\left(G_{i} \frac{f P A R_{i}}{0.95}-16 r_{10} \frac{C_{i-1}}{c n} \sigma_{i}\right)
$$

where $\frac{f_{P A R_{i}}}{0.95}$ is the fraction of total assimilation flux $G_{i}$ allocated to the above-ground plant biomass $\left(\mathrm{gCm}^{-2}\right)$ at time step $i$. The plant maintenance respiration is calculated as a function of leaf nitrogen, air temperature, and previous biomass $C_{i-1} . r_{10}$ is the plant tissue respiration rate at $10^{\circ} \mathrm{C} ; c n$ stands for plant carbon-to-nitrogen ratio; $\sigma_{i}$ is a scalar that modifies the respiration rate according to the daily air temperature [46].

\subsubsection{Gross Primary Productivity}

The total assimilation flux $G_{i},=$ also known as the gross primary productivity $(\mathrm{GPP})\left(\mathrm{gCm}^{-2} \cdot \mathrm{day}^{-1}\right)$, can be calculated using the remote sensing-based plant light use efficiency (LUE) approach. The chloroplasts use incoming solar radiation with a spectral range between $400 \mathrm{~nm}$ and $700 \mathrm{~nm}$ in photosynthesis [47].

$$
\begin{gathered}
G_{i}=P A R_{i} \times f P A R_{i} \times R U E_{i} \\
P A R=2.3\left(R_{O} \times \tau_{\partial}\right) \rho_{s w}
\end{gathered}
$$

where $\left(R_{O} \times \tau_{\partial}\right) \rho_{s w}$ represents the shortwave irradiance $\left(R_{s}\right), R_{O}$ is daily top-of-atmosphere shortwave irradiance $\left(\mathrm{J} / \mathrm{m}^{2} /\right.$ day) $[48,49], \tau_{\partial}$ is atmospheric transmissivity calculated using the Bristow-Campbell relationship $[50,51]$ calibrated for Australia, and $\rho_{s w}$ is the ratio of shortwave irradiance at a sloping surface to that at a horizontal surface [52].

FPAR is the portion of PAR that is absorbed by a photosynthetic organism, and it is estimated using a linear relation between $P P A R$ and rescaled NDVI by thresholds (i.e., local minimum and crop-specific maximum NDVIs) $[53,54]$. LUE is highly linearly related to a diffuse fraction $\left(f_{D}\right)$ and photosynthetic carbon flux [55].

$$
L U E_{i}=0.024 \times f_{D i}+0.00061 A_{x}
$$

where $A_{x}$ is the maximum photosynthetic capacity $\left(\mu \mathrm{molCm}{ }^{-2} \cdot \mathrm{s}^{-1}\right)$, which is a crop-specific parameter; is 23,40 , and 45 for barley [56], canola [57], and wheat [57], respectively; $f_{D}$ is the ratio of diffused to total solar irradiance varying from 0.2 (under clear skies) to 1.0 (under overcast skies) [48]. For a full description of C-Crop, see Donohue et al. [6].

\subsection{Validation}

Two sets of data are used for validation and further analysis, depending on the pixel-level completeness of time-series Landsat NDVIs at 25-m pixel resolution across the growing season (i: 8-19) between April (DOY 113) and October (DOY 304) (Figure S3, Supplementary Materials). Firstly, the coordinates of complete time-series Landsat pixels are used to obtain the resampled MODIS, L-M blended, and observed yield data for validation at the $25-\mathrm{m}$ resolution as the first dataset. Secondly, these complete time-series Landsat pixels are upscaled at $250 \mathrm{~m}$ pixel size to extract the MODIS and the L-M blended data with the same pixel size for the validation at the moderate resolution. Thirdly, the pixel-level yield predictions are aggregated for each respective field by averaging the yield values of the pixels within, for field-level validation. Fourthly, and finally, the predicted yields are evaluated using the model coefficient of determination $\left(R^{2}\right)$, the root-mean-square error (RMSE), and the mean bias error $(M B E)$. The $R^{2}$ describes the proportion of the response variable that can be explained by the model. RMSE gives more weight to the largest errors, and the MBE indicates the systematic error of the model to under or overestimate. These procedures are then repeated for the second dataset created 
according to the coordinates of incomplete time-series Landsat NDVIs at the 25-m pixel resolution. As C-Crop requires a time series of NDVI, the results are assessed without the incomplete time-series pixels of Landsat.

\subsection{Identification of Threshold for When to Blend}

The incomplete time-series pixels of Landsat are gap-filled with the L-M blended pixels $\left(L_{L M}\right)$. The threshold to indicate when blending is beneficial is identified by quantifying the impact of the fraction of missing data on the prediction accuracy at $25 \mathrm{~m}$. Firstly, we group MODIS and $L_{L M}$ time series in eight groups, based on the fraction of Landsat missing data $(<10 \%, 10-20 \%, 20-30 \%, 30-40 \%$, $40-50 \%, 50-60 \%, 60-70 \%$, and 70-80\%). Then, the accuracy of each group is analyzed by calculating the $R^{2}$ and the RMSE. The performance of C-Crop using MODIS and $L_{L M}$ is compared by the fraction of missing data in Landsat across time. The threshold can be identified, when the model provides the same $R^{2}$ and RMSE using $L_{L M}$ as with MODIS (Figure S3, Supplementary Materials). This threshold determines when, where, or how much L-M blended data improves crop yield prediction when the fraction of missing data in Landsat is lower than the identified threshold.

\subsection{Evaluation of the Improvement in Yield Prediction Accuracy}

The improvement in prediction accuracy using the identified threshold for multiple spatio-temporal data selection is statistically quantified. More specifically, the threshold is applied to the Landsat observations (2000-2018). Firstly, we compute the temporal probability of optimally using MODIS, Landsat, and $L_{L M}$ images for nationwide crop yield predictions during the past two decades, and then map the results to illustrate the spatial variability of multi-sensor data selection for 25-m pixel-level yield prediction across the wheatbelt. We then evaluate the area percentage of the data sources on a yearly basis and analyze their potential correlation to the annual precipitation (mm/year). Finally, the improvement in the accuracy of predicted yields is evaluated on the field level using MODIS and $L_{L M}$ for Western and eastern Australia, against the reported data [58]. The growing season of 2015 is selected due to the availability of a larger quantity of observed yield data. The incomplete 2015 Landsat series are gap-filled with the blended values corresponding to the threshold value.

\section{Results}

\subsection{Yield Prediction}

Exactly $66 \%$ of the observed fields have a complete time series of Landsat NDVIs at the pixel level across the growing season. For this dataset, C-Crop performs the best with Landsat images at field $\left(R^{2}=0.68\right.$; Figure 4a), 250-m $\left(R^{2}=0.85\right.$; Figure $\left.4 \mathrm{~d}\right)$, and $25-\mathrm{m}\left(R^{2}=0.48\right.$; Figure $\left.4 \mathrm{~g}\right)$ pixel resolutions for yield prediction pooled for wheat, barley, and canola. MODIS-based model yields were at least $10 \%$ less in terms of the $R^{2}$ than when using complete time-series Landsat data. The model performs almost identically when using MODIS and L-M blended data for the predictions at both field and pixel scales. However, it produces the lowest bias for field $(M B E=-0.32 \mathrm{t} / \mathrm{ha}$; Figure $4 \mathrm{c}), 250-\mathrm{m}(M B E=-0.23$; Figure $4 \mathrm{f})$, and 25-m ( $M B E=-0.21$; Figure 4i) pixels when using the L-M blended data. 

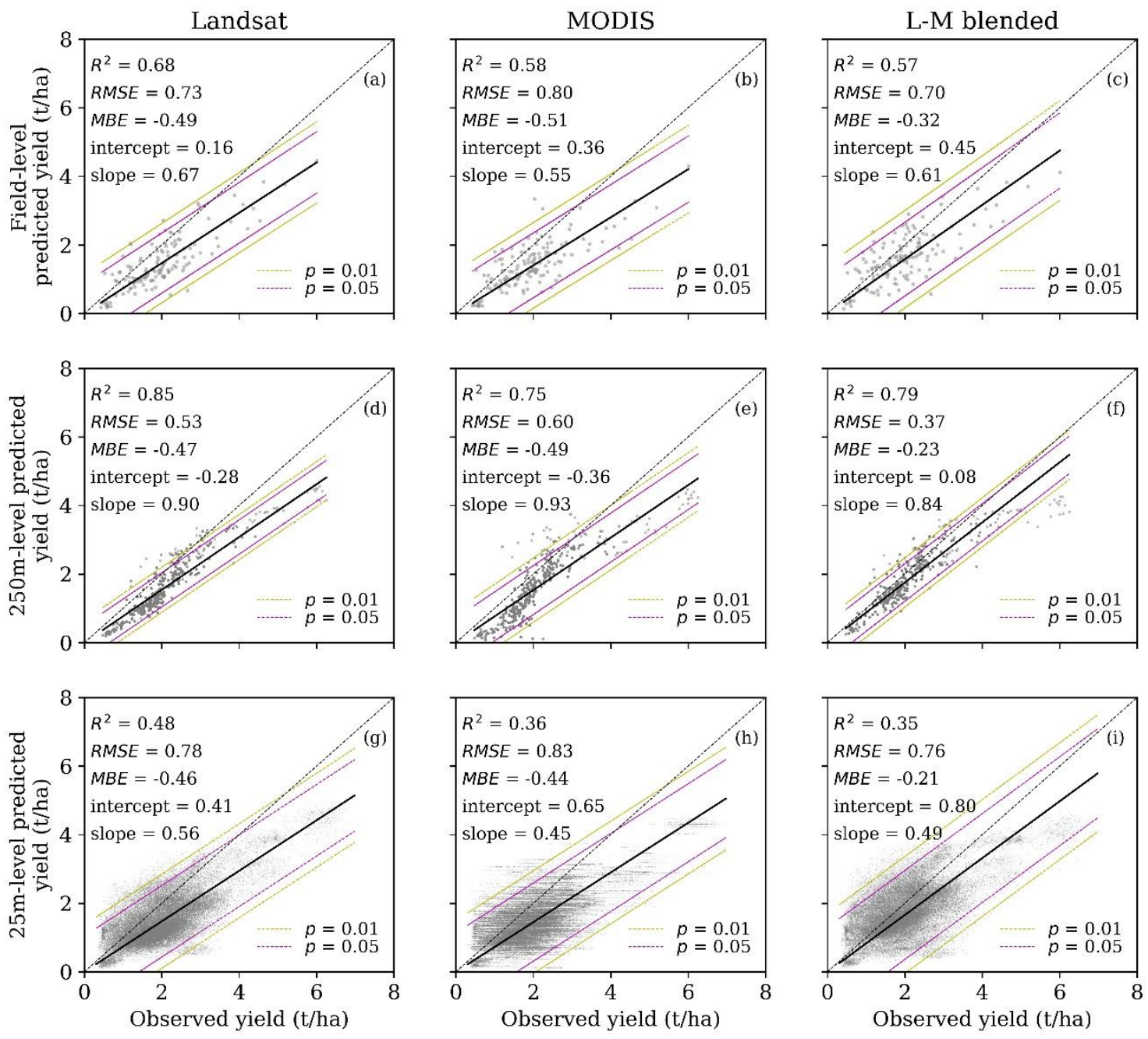

Figure 4. Validation of C-Crop-predicted yield pooled for wheat, barley, and canola using Landsat, MODIS, and L-M blended data where the complete Landsat time series are observed (the fraction of missing Landsat series $=0$ ). From top to bottom, the first $(\mathbf{a}-\mathbf{c})$, second $(\mathbf{d}-\mathbf{f})$, and third $(\mathbf{g}-\mathbf{i})$ rows show the comparison between observed ( $x$-axis) and model-predicted yields ( $y$-axis) on the field scale ( $n=139)$, 250-m pixel level $(n=2367)$, and 25-m pixel level $(n=113,329)$, respectively, where $n$ is the sample size. From left to right, the first $(\mathbf{a}, \mathbf{d}, \mathbf{g})$, second $(\mathbf{b}, \mathbf{e}, \mathbf{h})$, and third $(\mathbf{c}, \mathbf{f}, \mathbf{i})$ columns delineate the validation using Landsat, MODIS, and L-M blended data, respectively. The solid black line is the line of best fit, the purple and the yellow lines represent the upper and lower bounds of the prediction confidence intervals (i.e., $p=0.01$ and $p=0.05$ ), and the black dashed line is the 1:1 line.

Figure 5 shows that 210 fields have incomplete time-series Landsat pixels during the growing season. These series are incomplete due to clouds in some of the Landsat images acquired in the specific growing season when the yield data are observed. Using this set of data, the L-M blended data-based model performs the same as the MODIS-based model when aggregating to 250-m $\left(R^{2}=0.86, R M S E=0.52 \mathrm{t} / \mathrm{ha}, M B E=-0.40 \mathrm{t} / \mathrm{ha}\right.$; Figure $\left.5 \mathrm{c}, \mathrm{d}\right)$ and field $\left(R^{2}=0.66, R M S E=0.82 \mathrm{t} / \mathrm{ha}\right.$, $M B E=-0.49 \mathrm{t} / \mathrm{ha}$; Figure $5 \mathrm{a}, \mathrm{b})$ scales. The $\mathrm{L}-\mathrm{M}$ blended data-based model shows its advantages at the 25-m pixel level, which explains an extra $7 \%$ of the variability in the observed yields when the Landsat time-series pixels are incomplete (Figure $5 \mathrm{e}, \mathrm{f})$. 

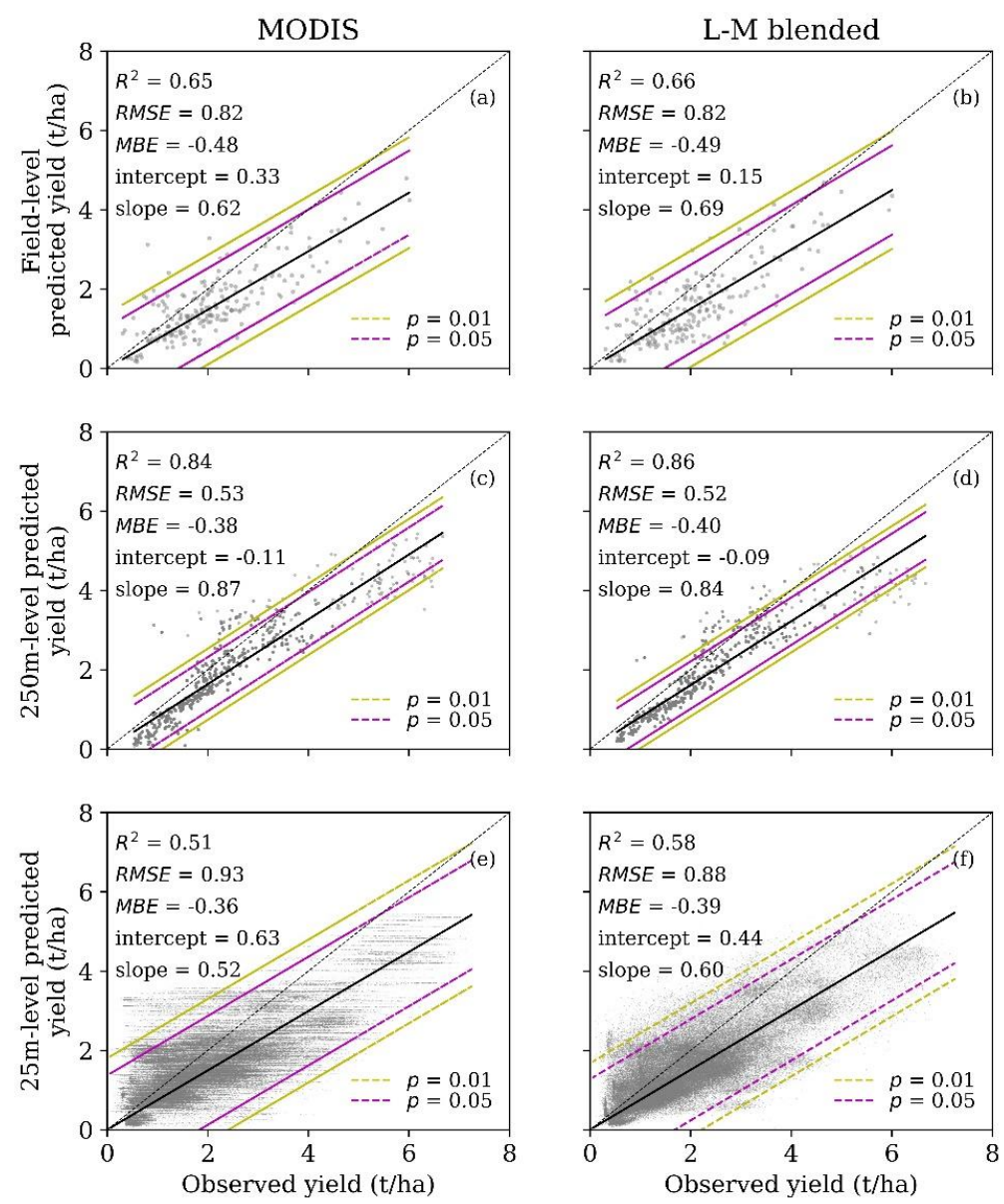

Figure 5. Validation of C-Crop-predicted yield pooled for wheat, barley, and canola using MODIS and L-M blended data when the complete Landsat time series are not available (the fraction of missing Landsat series $\geq 0.083)$. From top to bottom, the first $(\mathbf{a}, \mathbf{b})$, second $(\mathbf{c}, \mathbf{d})$, and third $(\mathbf{e}, \mathbf{f})$ rows show the comparison between observed ( $x$-axis) and model-predicted yields ( $y$-axis) on the field scale $(n=210)$, 250-m pixel level ( $n=3978)$, and 25-m pixel level $(n=231,667)$, respectively, where $n$ is the sample size. From left to right, the first $(\mathbf{a}, \mathbf{c}, \mathbf{e})$ and second $(\mathbf{b}, \mathbf{d}, \mathbf{f})$ columns delineate the validation using MODIS and L-M blended data, respectively. The solid black line is the line of best fit, the purple and the yellow lines represent the upper and lower bounds of the prediction confidence intervals (i.e., $p=0.01$ and $p=0.05)$, and the black dashed line is the 1:1 line.

\subsection{Identification of the Threshold}

Figure 6a shows that the 25-m pixel-level yield prediction accuracy fluctuates between 0.35 and 0.75 using MODIS and $L_{L M}$ data in time and space, where time-series Landsat observations are incomplete. The $R^{2}$ derived from MODIS is steady (between 0.4 and 0.5$)$ where the fraction of missing Landsat data ranged between 0.05 and 0.42 , which is lower than the $R^{2}(0.62-0.5)$ derived from $L_{L M}$ data. The RMSE derived from both data sources remains approximately $0.9 \mathrm{t} / \mathrm{ha}$ for the same fraction of missing Landsat data (Figure $6 \mathrm{~b}$ ). When more incomplete time-series Landsat data are observed (from 0.42 to 0.75 on both Figure $6 a, b$ ), the $R^{2}$ based on MODIS increases to around 0.7 and the RMSE decreases to $0.4 \mathrm{t} / \mathrm{ha}$ (as MODIS is not as cloud-affected as Landsat due to imagery being acquired on more days), whereas the $R^{2}$ derived from the $L_{L M}$ fluctuates between 0.6 and 0.4 and the RMSE changes between 1.3 and $0.8 \mathrm{t} /$ ha (Figure 6). Given this, up to $42 \%$ of missing Landsat data in the growing season is defined as the threshold for when L-M blending is optimal to implement. That is, the 25-m pixel-level yield prediction accuracy can be improved using $L_{L M}$ when the fraction of missing Landsat data at the coordinates is below this threshold. For instance, the $L_{L M}$-based model increases $R^{2}$ by up to $20 \%$ when the fraction of the missing Landsat data is below $42 \%$ (Figure $6 a$ ). 

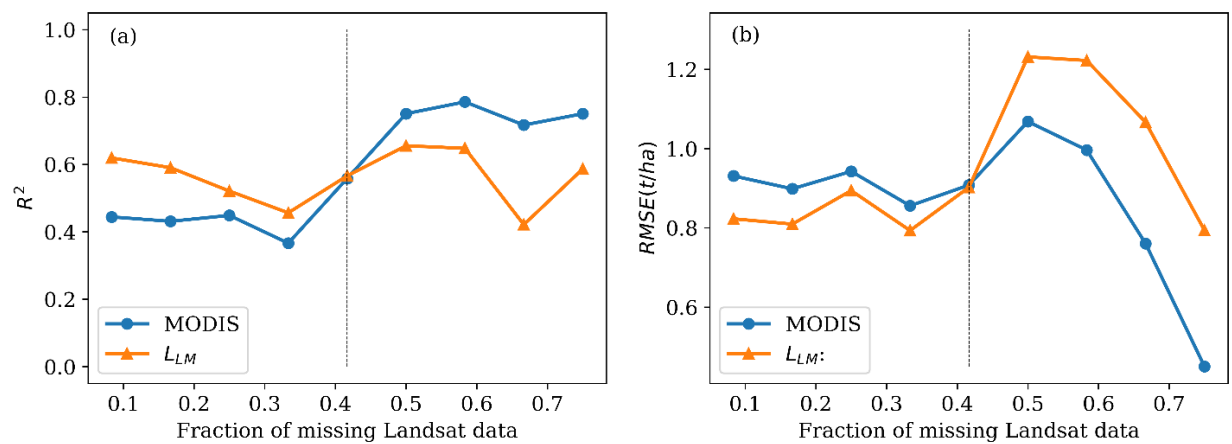

Figure 6. The statistical analysis of missing data in Landsat for 25-m pixel-level yield prediction, by evaluating (a) $R^{2}$ and (b) RMSE against the fraction of Landsat missing data during the growing season. L-M blended data were used to fill the gaps $\left(L_{L M}\right)$ in the incomplete Landsat series.

\subsection{Evaluation of the Improvement in Yield Prediction Accuracy}

Given the availability of cloud-free Landsat and MODIS data across the wheatbelt (2000-2018), in concert with the previously determined threshold (Figure 6) and finding (Figure 5), we can demonstrate which imagery (i.e., either MODIS, Landsat, and $L_{L M}$ ) is best suitable for 25-m pixel-level crop yield prediction (Figure 7). Figure 7 shows the selection when using multiple satellite products for crop yield estimates across the wheatbelt over the past two decades. For the wheatbelt north of $35^{\circ}$ south (S), there is a higher probability of obtaining complete cloud-free Landsat observations over the growing season in the east-west overlapping areas of adjacent Landsat Path-Rows, whilst $L_{L M}$ is optimal elsewhere north of $35^{\circ} \mathrm{S}$. South of $35^{\circ} \mathrm{S}$, MODIS is optimal, with $L_{L M}$ being optimal in the east-west overlapping areas of adjacent Landsat Path-Rows (in Figure 7).

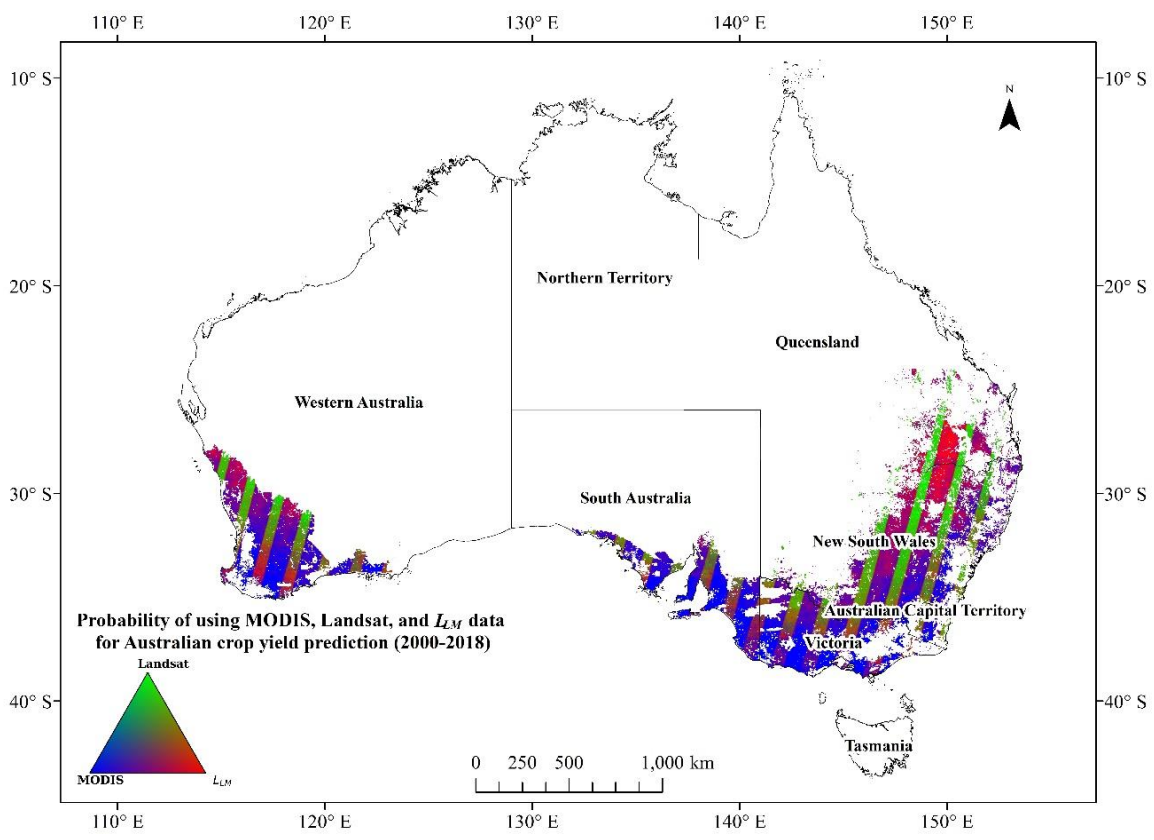

Figure 7. Multi-sensor optimal data selection across the wheatbelt (2000-2018) for 25-m pixel-level crop yield prediction, using the probability of MODIS, Landsat, and $L_{L M}$ images. Blue denotes regions where incomplete Landsat series have a fraction of missing data exceeding $42 \%$, thus indicating where MODIS should be used for yield estimates because it provides more frequent observations than Landsat. Green areas show where adjacent Landsat orbits overlap and, thus, where a complete once every 16-day Landsat series over the whole growing season is available. Areas colored red are those where the fraction of Landsat missing data is below the 0.42 threshold identified previously in Figure 6 when L-M blended data improve the yield prediction accuracy. 
For 25-m pixel-level yield prediction, blended data should be preferred on average for $33 \%$ of the Australian wheatbelt area (Figure 8a). MODIS and Landsat data remain the preferred data sources in $50 \%$ and $17 \%$ of cases, respectively. Figure $8 \mathrm{~b}$ shows that the area percentage is positively correlated with annual precipitation for MODIS and negatively correlated for Landsat and the L-M blended data. MODIS has a larger scatter when annual precipitation is greater than $400 \mathrm{~mm} /$ year.
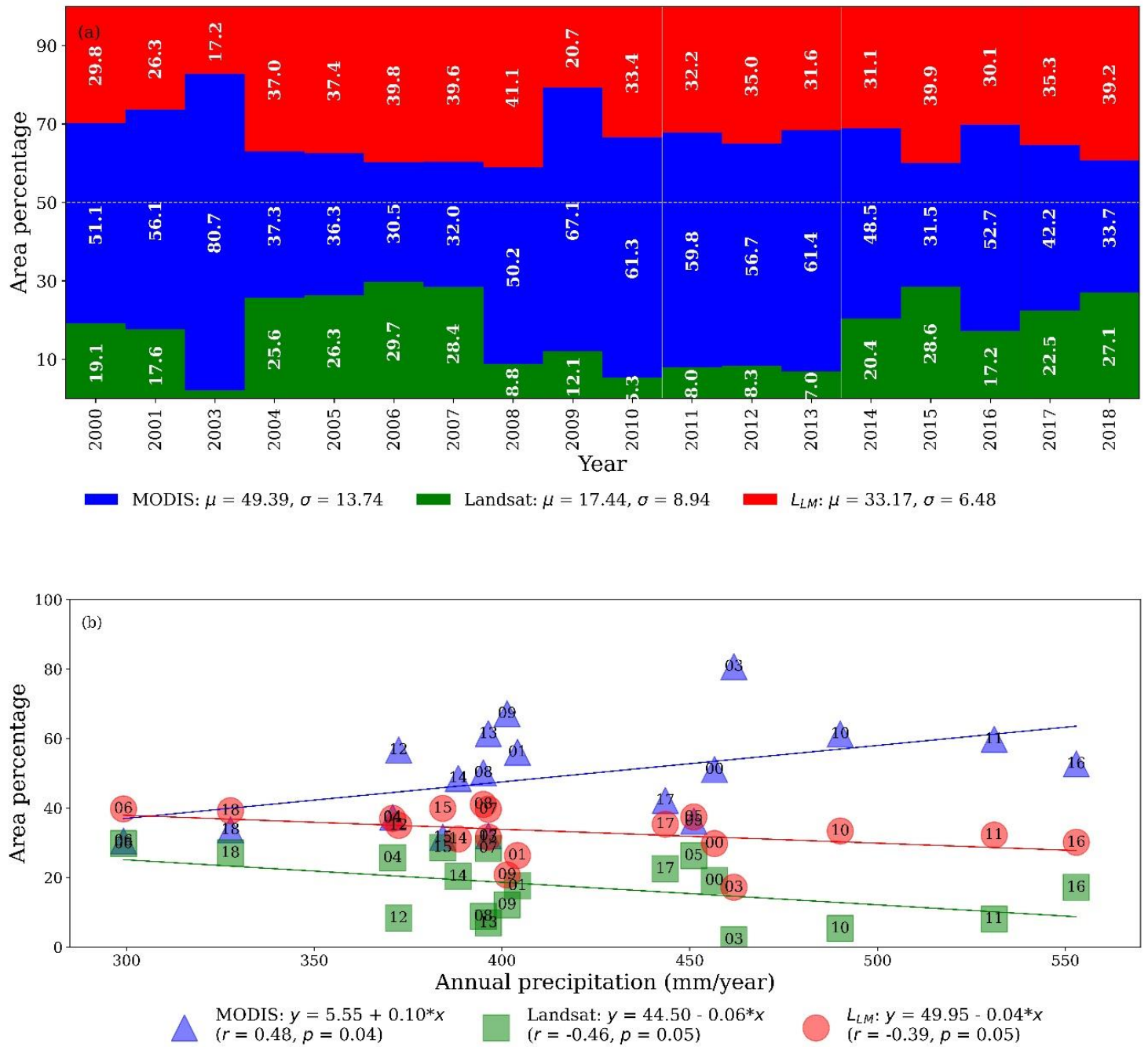

Figure 8. Yearly analysis of multi-sensor data selection for 25-m pixel-level crop yield prediction (2000-2018) by evaluating (a) the area percentage and (b) its correlation with the annual precipitation (mm/year). The white dashed line shows that the area percentage is $50 . \mu$ : mean of population values; $\sigma$ : standard deviation; $r$ : correlation coefficient. The symbols in (b) are labeled with the last two digits of the year.

Of the 53-million-ha Australia wheatbelt, complete Landsat time series were suitable for $28.6 \%$ of that area, MODIS for $31.5 \%$, and $L_{L M}$ for $39.9 \%$ during the 2015 growing season (Figure $8 \mathrm{a}$ ). In this season, there are 104 fields available for assessing the accuracy improvement in yield prediction accuracy for nationwide crop yield prediction (Table S1, Supplementary Materials). Within these observed yield data, 69 fields are located where L-M blended images can improve the prediction accuracy according to the previously defined (see Figure 6) $42 \%$ Landsat missing data threshold. Figure 9 shows the predicted yields against the observed values for 63 fields in Western Australia (i.e., WA), and six fields in eastern Australia (i.e., Queensland (QLD), New south Wales (NSW), Victoria (VIC), and South Australia (SA)). 

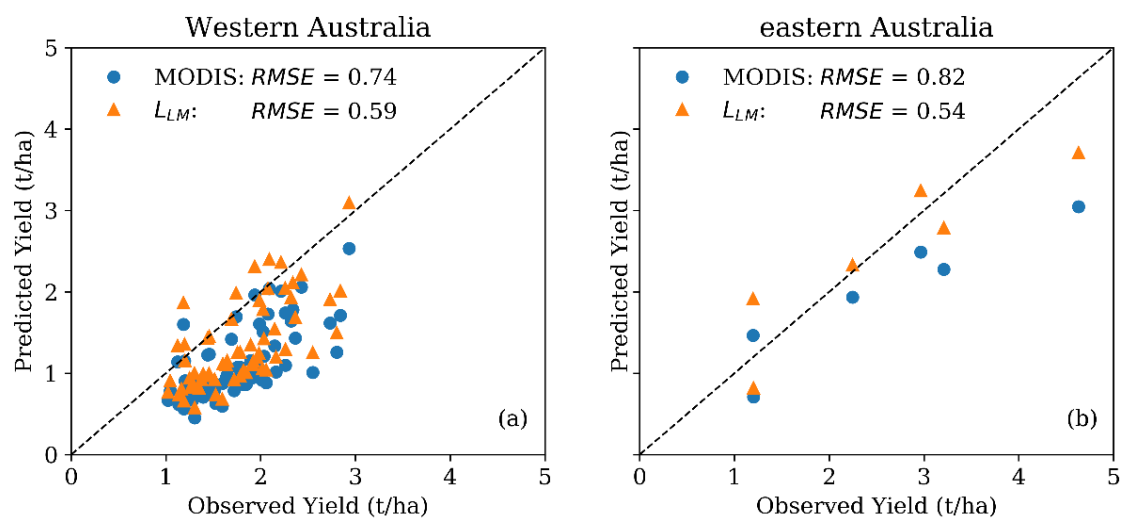

Figure 9. Scattergram for C-Crop-predicted yield against observed values for 2015 at the field level for (a) Western Australia $(n=63)$ and (b) eastern Australia $(n=6)$ wheatbelt using MODIS and L-M blended data for gap-filling Landsat $\left(L_{L M}\right)$ when the fraction of incomplete Landsat series is below $42 \%$ for the growing season. The RMSE statistics have units of $\mathrm{t} / \mathrm{ha}$.

In these areas (see Figure 9), when the fraction of incomplete Landsat series across the growing season of 2015 falls below $42 \%$, using $L_{L M}$ reduced the field-level yield prediction errors by $0.15 \mathrm{t} / \mathrm{ha}$ for Western Australia and $0.28 \mathrm{t} / \mathrm{ha}$ for eastern Australia. More specifically, the bias of 598 kilotons in grain production over the cropping area of $39,882 \mathrm{~km}^{2}$ in Western Australia and of 1672 kilotons in grain production over the cropping area of $59,716 \mathrm{~km}^{2}$ in eastern Australia can be decreased when using the threshold determined herein to decide the areas where the blended data can improve the prediction accuracy.

\section{Discussion}

Globally, wheat-growing regions are distributed within areas that experience a relatively high frequency of clouds [59]. Persistent cloud cover limits the use of HSR sensors over large spatial extents due to the low frequency of the observations, whereas the other sensors that have HTF are constrained by the LSR. Although blending improves the monitoring of rapidly changing processes such as crop growth, it may introduce unforeseen spatial and temporal variances in the blended images when images are often not observed concurrently [10], and implementing the current suite of algorithms across large areas is currently computationally expensive. Therefore, it is important to systematically quantify and evaluate the utility of blending imagery across time and space before embarking on the development of nationwide blending capabilities.

This study developed a parsimonious approach to identify when and where blending is beneficial for crop yield prediction at the $25-\mathrm{m}$ pixel resolution. When incomplete Landsat series falls below $42 \%$ of the possible imagery in the growing season, blending is recommended because it improves the accuracy of the yield estimates. When incomplete Landsat series exceeds $42 \%$ of data, the use of HTF LSR data (e.g., MODIS) for the 25-m pixel-level yield prediction is recommended, reducing the computational need for blending. LTF HSR data show benefits, for example, in providing detailed information on plant photosynthesis across space; thus, they should be solely used for crop yield prediction when enough cloud-free images are available throughout the growing season.

Annual precipitation, which is strongly associated with cloudiness [60,61] and, thus, partly governs the amount of missing Landsat data, indicates which data sources should be preferably used (Figure 8). For instance, MODIS should be used for the prediction for greater than $50 \%$ of the wheatbelt during wet years (e.g., 2003, 2010, 2011, and 2016). During dry years (e.g., 2006 and 2018), the proportion of the wheatbelt where Landsat is suitable for yield prediction increases by $>10 \%$ compared to the average proportion (17\%). For crop yield prediction, blended data can be optimally applied across approximately $33 \%$ of the wheatbelt during dry to normal years. 
Crop production fluctuates from year to year due to the rapidly changing patterns of precipitation and temperature $[42,62,63]$. Over the last 50 years, the amount of precipitation received by the Australian wheatbelt declined [64]. Based on model projections, it was also suggested that the changing climatic conditions will affect both the frequency and intensity of the extreme events such as floods, heatwaves, and droughts, which will impact agricultural production $[65,66]$. Within the context of the present study, an increase in the number of clear sky days can be beneficial for the use of RS in crop yield forecasting. Moreover, a decline in the number of rain days in recent decades within the wheatbelt area can also be noted (see Figure S4, Supplementary Materials). Here, this decline in the number of rain days is assumed to correlate with the increase in the number of days with clear skies. However, a decrease in the number of rain days does not necessarily imply an absence of clouds, as there could be non-precipitating clouds. However, studies such as Norris et al. [67], using observations and Coupled Model Intercomparison Project Phase 5 (CMIP5) model outputs, showed that, on average, there is a decline in cloud amount across the region from $60^{\circ} \mathrm{S}-60^{\circ}$ north $(\mathrm{N})$. This decline was attributed to the poleward shift of mid-latitude storm tracks, among others.

The potential influence of climate change on grain production suggests a decline in world food supply [68] and an increase in the level of exposure of the global population to the risk of hunger [69]. It is, therefore, important to ensure the accuracy and efficiency of yield prediction at anytime, anywhere, and at any scale. A more precise description of grain weight patterns in time and space provides more accurate information for precision agriculture to improve its production and sustainability. The semi-empirical carbon turn-over model used for crop yield prediction is based on historical yield data, and, in the future, relevant drivers (e.g., precipitation and temperature) and their interactions may change under climate change, thus requiring model re-calibration $[4,6,70,71]$. Our approach was tested with C-Crop but could be extended to other semi-empirical models [72] and models based on machine learning [73].

Development of a national-scale yield prediction system requires time series of HSR and HTF imagery to describe the crop growth; therefore, next-generation HSR and HTF satellite data like Sentinel-2 [74,75] should be tested for nationwide yield estimates post the growing season of 2015 . Harmonized Landsat and Sentinel-2 surface reflectance products should be tested for national-scale crop yield prediction [76] when observed yield data for more recent years are available. However, spatio-temporal fusion of MODIS and Landsat data is still necessary for long-term studies that involve historical satellite images collected before 2015 (back to the year 2000, when MODIS was launched). Future studies should also focus on using active RS technologies, such as radio detecting and ranging (Radar) [77,78] and light detection and ranging (LiDAR) [79], for a national yield estimation because of their ability to penetrate clouds and detect a plant's three-dimensional structural characteristics. Data blending between HSR optical imagery and active RS data (e.g., Radar and LiDAR) [80] warrants further study.

\section{Conclusions}

Sparse time series of satellite remote sensing, due to LTF and/or cloud contamination, represent one of the main barriers limiting accurate crop yield estimation at regional to national scales. Blending of HSR but LTF images with LSR but HTF images was proposed to increase the temporal resolution and maintain spatial details. In this study, the benefits of blending were tested for crop yield prediction across the Australian wheatbelt. We found that, when time series are gap-free, yield prediction from Landsat is the most accurate on both field and pixel scales. When Landsat time series contain $<42 \%$ missing values during the growing season, blending is recommended for nationwide crop yield prediction at the $25-\mathrm{m}$ pixel resolution. When Landsat time series contain $\geq 42 \%$ missing observations, MODIS outperforms blending. Across Australia, these recommendations would improve yield estimates by $0.15 \mathrm{t} / \mathrm{ha}$ for Western Australia and $0.28 \mathrm{t} / \mathrm{ha}$ for eastern Australia on average. By identifying where and when to blend, this work paves the way to more accurate monitoring of biophysical processes and yields, while keeping computational costs low. 
Supplementary Materials: The following are available online at http://www.mdpi.com/2072-4292/12/10/1653/s1, Table S1: Summary of observed data (the number of field-years) used herein; Figure S1. Long-term (1901-2018) average monthly accumulated precipitation ( $\mathrm{mm} / \mathrm{month}$ ) (left) and the long-term average rain days (right) across the wheatbelt for $(a, b)$ Queensland, (c, d) New South Wales, (e, f) Victoria, ( $g$, h) South Australia, (i, j) Western Australia, and $(k, 1)$ Tasmania. The precipitation data are sourced from Jeffrey et al. [37], and the wheat belt mask was resampled from native $2-\mathrm{km}^{2}$ horizontal resolution onto the precipitation data grid with $5-\mathrm{km}^{2}$ horizontal resolution using nearest neighbor [40]. The vertical black lines (a-f) represent one standard deviation of the monthly wheatbelt specific precipitation for each state. The horizontal line $(\mathrm{g}-\mathrm{l})$ represents the median of the data, the box spans from 25th to 75th quartiles of the data, and the rain day threshold is $0 \mathrm{~mm} /$ day. It should be noted that Northern Territory is not included in the analysis due to its small cropping area; Figure S2. An example of MODIS and Landsat blended NDVI using ESTARFM. The $x$-axis and $y$-axis are time $(t, \mathrm{DOY})$ and spatial resolution (m), respectively. Both MODIS and Landsat have valid observations at $t_{1}$ and $t_{2}$. The image at the center of the top row is a valid observation of MODIS at $t_{s}$, and that at the center of the bottom row is Landsat-like blended data at $t_{s}$ created using the 16-day MODIS composite images on the DOYs 257, 273, and 289, as well as the Landsat images acquired on the DOYs 257 and 289; Figure S3: The implementation flowchart of validation and identification of threshold for when to blend. The shaded areas indicate the original data sources; Figure S4: Long-term (1900-2018) average monthly accumulated precipitation (mm/month) across (a) eastern Australian, (b) Western Australia, and (c) the wheatbelt. The precipitation data are sourced from Jeffrey et al. [37].

Author Contributions: Conceptualization, Y.C., T.R.M., and R.J.D.; methodology, Y.C.; software, N.O. and N.G.; validation, Y.C.; formal analysis, Y.C.; investigation, Y.C. and F.W.; resources, L.L. and N.G.; writing-original draft preparation, Y.C.; writing-review and editing, T.R.M., R.J.D., F.W., N.G., and R.L.; visualization, Y.C. and N.G.; supervision, T.R.M. and R.J.D.; project administration, R.L.; funding acquisition, R.L. All authors read and agreed to the published version of the manuscript.

Funding: The authors acknowledged the support of the Digiscape Future Science Platform, funded by the CSIRO.

Acknowledgments: Appreciation is extended to numerous industry participants who provided training data in the form of yield maps, accessed by the project team. Randall J. Donohue and Tim R. McVicar acknowledge the support of the ARC Center of Excellence for Climate Extremes (Australian Research Council grant CE170100023). We thank the two anonymous reviewers and the Remote Sensing Academic Editor for helpful comments that helped us improve this paper.

Conflicts of Interest: The authors declare no conflicts of interest.

\section{References}

1. Cohen, J.E. Human population: The next half century. Science 2003, 302, 1172-1175. [CrossRef]

2. Jones, J.W.; Antle, J.M.; Basso, B.; Boote, K.J.; Conant, R.T.; Foster, I.; Godfray, H.C.J.; Herrero, M.; Howitt, R.E.; Janssen, S.; et al. Brief history of agricultural systems modeling. Agric. Syst. 2017, 155, 240-254. [CrossRef] [PubMed]

3. Prasad, A.K.; Chai, L.; Singh, R.P.; Kafatos, M. Crop yield estimation model for Iowa using remote sensing and surface parameters. Int. J. Appl. Earth Obs. Geoinf. 2006, 8, 26-33. [CrossRef]

4. Doraiswamy, P.C.; Moulin, S.; Cook, P.W.; Stern, A. Crop yield assessment from remote sensing. Photogramm. Eng. Remote Sens. 2003, 69, 665-674. [CrossRef]

5. Serrano, L.; Filella, I.; Penuelas, J. Remote sensing of biomass and yield of winter wheat under different nitrogen supplies. Crop. Sci. 2000, 40, 723-731. [CrossRef]

6. Donohue, R.J.; Lawes, R.A.; Mata, G.; Gobbett, D.; Ouzman, J. Towards a national, remote-sensing-based model for predicting field-scale crop yield. Field Crop. Res. 2018, 227, 79-90. [CrossRef]

7. Myers, E.; Kerekes, J.; Daughtry, C.; Russ, A. Assessing the Impact of Satellite Revisit Rate on Estimation of Corn Phenological Transition Timing through Shape Model Fitting. Remote Sens. 2019, 11, 2558. [CrossRef]

8. Waldner, F.; Chen, Y.; Horan, H.; Hochan, Z. High temporal resolution of leaf area data improves empirical estimation of grain yield. Sci. Rep. Press 2019, 9, 1-4. [CrossRef]

9. Sakamoto, T.; Gitelson, A.A.; Arkebauer, T.J. Near real-time prediction of US corn yields based on time-series MODIS data. Remote Sens. Environ. 2014, 147, 219-231. [CrossRef]

10. Emelyanova, I.V.; McVicar, T.R.; Van Niel, T.G.; Li, L.T.; van Dijk, A.I.J.M. Assessing the accuracy of blending Landsat-MODIS surface reflectances in two landscapes with contrasting spatial and temporal dynamics: A framework for algorithm selection. Remote Sens. Envrion. 2013, 133, 193-209. [CrossRef]

11. Zhu, X.; Chen, J.; Gao, F.; Chen, X.; Masek, J.G. An enhanced spatial and temporal adaptive reflectance fusion model for complex heterogeneous regions. Remote Sens. Environ. 2010, 114, 2610-2623. [CrossRef] 
12. Gao, F.; Masek, J.; Schwaller, M.; Hall, F. On the blending of the Landsat and MODIS surface reflectance: Predicting daily Landsat surface reflectance. IEEE Trans. Geosci. Remote Sens. 2006, 44, 2207-2218.

13. ABS. Themes: Land Use on Farms, Australia, Year Ended 30 June 2017; Australian Bureau of Statistics: Canberra, Australia, 2017. Available online: http://www.abs.gov.au/ausstats/abs@.nsf/mf/4627.0 (accessed on 7 April 2020).

14. Duveiller, G.; Baret, F.; Defourny, P. Crop specific green area index retrieval from MODIS data at regional scale by controlling pixel-target adequacy. Remote Sens. Environ. 2011, 115, 2686-2701. [CrossRef]

15. Waldner, F.; Defourny, P. Where can pixel counting area estimates meet user-defined accuracy requirements? Int. J. Appl. Earth Obs. Geoinf. 2017, 60, 1-10. [CrossRef]

16. Whitcraft, A.; Becker-Reshef, I.; Killough, B.; Justice, C. Meeting earth observation requirements for global agricultural monitoring: An evaluation of the revisit capabilities of current and planned moderate resolution optical earth observing missions. Remote Sens. 2015, 7, 1482-1503. [CrossRef]

17. Lobell, D.B.; Thau, D.; Seifert, C.; Engle, E.; Little, B. A scalable satellite-based crop yield mapper. Remote Sens. Environ. 2015, 164, 324-333. [CrossRef]

18. Schowengerdt, R.A. Remote Sensing: Models and Methods for Image Processing; Elsevier: Amsterdam, The Netherlands, 2006.

19. Kang, S.; Running, S.W.; Zhao, M.; Kimball, J.S.; Glassy, J. Improving continuity of MODIS terrestrial photosynthesis products using an interpolation scheme for cloudy pixels. Int. J. Remote Sens. 2005, 26, 1659-1676. [CrossRef]

20. Poggio, L.; Gimona, A.; Brown, I. Spatio-temporal MODIS EVI gap filling under cloud cover: An example in Scotland. ISPRS J. Photogramm. Remote Sens. 2012, 72, 56-72. [CrossRef]

21. Borak, J.S.; Jasinski, M.F. Effective interpolation of incomplete satellite-derived leaf-area index time series for the continental United States. Agric. For. Meteorol. 2009, 149, 320-332. [CrossRef]

22. Jarihani, A.; McVicar, T.; Van Niel, T.; Emelyanova, I.; Callow, J.; Johansen, K. Blending Landsat and MODIS data to generate multispectral indices: A comparison of "Index-then-Blend" and "Blend-then-Index" approaches. Remote Sens. 2014, 6, 9213-9238. [CrossRef]

23. Zhang, J. Multi-source remote sensing data fusion: Status and trends. Int. J. Image Data Fusion 2010, 1, 5-24. [CrossRef]

24. Pohl, C.; Van Genderen, J.L. Review article multisensor image fusion in remote sensing: Concepts, methods and applications. Int. J. Remote Sens. 1998, 19, 823-854. [CrossRef]

25. Viovy, N.; Arino, O.; Belward, A. The Best Index Slope Extraction (BISE): A method for reducing noise in NDVI time-series. Int. J. Remote Sens. 1992, 13, 1585-1590. [CrossRef]

26. Löw, F.; Biradar, C.; Dubovyk, O.; Fliemann, E.; Akramkhanov, A.; Narvaez Vallejo, A.; Waldner, F. Regional-scale monitoring of cropland intensity and productivity with multi-source satellite image time series. GIsci. Remote Sens. 2018, 55, 539-567. [CrossRef]

27. Dong, T.; Liu, J.; Qian, B.; Zhao, T.; Jing, Q.; Geng, X.; Wang, J.; Huffman, T.; Shang, J. Estimating winter wheat biomass by assimilating leaf area index derived from fusion of Landsat-8 and MODIS data. Int. J. Appl. Earth Obs. Geoinf. 2016, 49, 63-74. [CrossRef]

28. Meng, J.; Du, X.; Wu, B. Generation of high spatial and temporal resolution NDVI and its application in crop biomass estimation. Int. J. Digit. Earth 2013, 6, 203-218. [CrossRef]

29. Wang, L.; Tian, Y.; Yao, X.; Zhu, Y.; Cao, W. Predicting grain yield and protein content in wheat by fusing multi-sensor and multi-temporal remote-sensing images. Field Crop. Res. 2014, 164, 178-188. [CrossRef]

30. Gao, F.; Anderson, M.C.; Zhang, X.; Yang, Z.; Alfieri, J.G.; Kustas, W.P.; Mueller, R.; Johnson, D.M.; Prueger, J.H. Toward mapping crop progress at field scales through fusion of Landsat and MODIS imagery. Remote Sens. Environ. 2017, 188, 9-25. [CrossRef]

31. Semmens, K.A.; Anderson, M.C.; Kustas, W.P.; Gao, F.; Alfieri, J.G.; McKee, L.; Prueger, J.H.; Hain, C.R.; Cammalleri, C.; Yang, Y. Monitoring daily evapotranspiration over two California vineyards using Landsat 8 in a multi-sensor data fusion approach. Remote Sens. Environ. 2016, 185, 155-170. [CrossRef]

32. Yang, Y.; Anderson, M.C.; Gao, F.; Wardlow, B.; Hain, C.R.; Otkin, J.A.; Alfieri, J.; Yang, Y.; Sun, L.; Dulaney, W. Field-scale mapping of evaporative stress indicators of crop yield: An application over Mead, NE, USA. Remote Sens. Environ. 2018, 210, 387-402. [CrossRef] 
33. Gao, F.; Anderson, M.; Daughtry, C.; Johnson, D. Assessing the variability of corn and soybean yields in central Iowa using high spatiotemporal resolution multi-satellite imagery. Remote Sens. 2018, 10, 1489. [CrossRef]

34. He, M.; Kimball, J.; Maneta, M.; Maxwell, B.; Moreno, A.; Beguería, S.; Wu, X. Regional crop gross primary productivity and yield estimation using fused landsat-MODIS data. Remote Sens. 2018, 10, 372. [CrossRef]

35. Liao, C.; Wang, J.; Dong, T.; Shang, J.; Liu, J.; Song, Y. Using spatio-temporal fusion of Landsat-8 and MODIS data to derive phenology, biomass and yield estimates for corn and soybean. Sci. Total Environ. 2019, 650, 1707-1721. [CrossRef] [PubMed]

36. Holper, P.N. Climate Change, Science Information Paper: Australian Rainfall-Past, Present and Future; CSIRO: Canberra, Australia, 2011.

37. Jeffrey, S.J.; Carter, J.O.; Moodie, K.B.; Beswick, A.R. Using spatial interpolation to construct a comprehensive archive of Australian climate data. Environ. Model. Softw. 2001, 16, 309-330. [CrossRef]

38. Li, F.; Jupp, D.L.; Reddy, S.; Lymburner, L.; Mueller, N.; Tan, P.; Islam, A. An evaluation of the use of atmospheric and BRDF correction to standardize Landsat data. IEEE J. Sel. Top. Appl. Earth Obs. Remote Sens. 2010, 3, 257-270. [CrossRef]

39. Rouse, J.W., Jr.; Haas, R.; Schell, J.; Deering, D. Monitoring Vegetation Systems in the Great Plains with ERTS; NASA: Washington, DC, USA, 1974.

40. Sibson, R. A brief description of natural neighbour interpolation. In Interpreting Multivariate Data; John Wiley \& Sons: New York, NY, USA, 1981; pp. 21-36.

41. Cockram, J.; Jones, H.; Leigh, F.J.; O'Sullivan, D.; Powell, W.; Laurie, D.A.; Greenland, A.J. Control of flowering time in temperate cereals: Genes, domestication, and sustainable productivity. J. Exp. Bot. 2007, 58, 1231-1244. [CrossRef] [PubMed]

42. Hochman, Z.; Gobbett, D.L.; Horan, H. Climate trends account for stalled wheat yields in Australia since 1990. Glob. Chang. Biol. 2017, 23, 2071-2081. [CrossRef]

43. Emelyanova, I.V.; McVicar, T.R.; Van Niel, T.G.; Li, L.T.; Van Dijk, A.I.J.M. On blending Landsat-MODIS surface reflectances in two landscapes with contrasting spectral, spatial and temporal dynamics. In WIRADA Project 3.4: Technical Report; CSIRO: Water for a Healthy Country Flagship: Canberra, Australia, 2012; p. 72. Available online: https://publications.csiro.au/rpr/pub?list=SEA\&pid=csiro:EP128838 (accessed on 7 April 2020).

44. Bramley, R.; Williams, S. A Protocol for the Construction of Yield Maps from Data Collected Using Commercially Available Grape Yield Monitors; Cooperative Research Centre for Viticulture: Adelaide, Australia, 2001.

45. Kira, T. Primary production of forests. In Photosynthesis and Productivity in Different Environments; Cambridge University Press: Cambridge, UK, 1975.

46. Sitch, S.; Smith, B.; Prentice, I.C.; Arneth, A.; Bondeau, A.; Cramer, W.; Kaplan, J.; Levis, S.; Lucht, W.; Sykes, M.T. Evaluation of ecosystem dynamics, plant geography and terrestrial carbon cycling in the LPJ dynamic global vegetation model. Glob. Chang. Biol. 2003, 9, 161-185. [CrossRef]

47. McCree, K.J. Test of current definitions of photosynthetically active radiation against leaf photosynthesis data. Agric. Meteorol. 1972, 10, 443-453. [CrossRef]

48. Roderick, M.L. Estimating the diffuse component from daily and monthly measurements of global radiation. Agric. For. Meteorol. 1999, 95, 169-185. [CrossRef]

49. Iqbal, M. An Introduction to Solar Radiation; Elsevier: Amsterdam, The Netherlands, 2012.

50. Bristow, K.L.; Campbell, G.S. On the relationship between incoming solar radiation and daily maximum and minimum temperature. Agric. For. Meteorol. 1984, 31, 159-166. [CrossRef]

51. McVicar, T.R.; Jupp, D.L. Estimating one-time-of-day meteorological data from standard daily data as inputs to thermal remote sensing based energy balance models. Agric. For. Meteorol. 1999, 96, 219-238. [CrossRef]

52. Wilson, J.P.; Gallant, J.C. Terrain analysis: Principles and Applications; John Wiley \& Sons: New York, NY, USA, 2000.

53. Verger, A.; Baret, F.; Camacho, F. Optimal modalities for radiative transfer-neural network estimation of canopy biophysical characteristics: Evaluation over an agricultural area with CHRIS/PROBA observations. Remote Sens. Environ. 2011, 115, 415-426. [CrossRef]

54. Li, W.; Weiss, M.; Waldner, F.; Defourny, P.; Demarez, V.; Morin, D.; Hagolle, O.; Baret, F. A generic algorithm to estimate LAI, FAPAR and FCOVER variables from SPOT4_HRVIR and Landsat sensors: Evaluation of the consistency and comparison with ground measurements. Remote Sens. 2015, 7, 15494-15516. [CrossRef] 
55. Donohue, R.J.; Hume, I.; Roderick, M.; McVicar, T.R.; Beringer, J.; Hutley, L.; Gallant, J.C.; Austin, J.; van Gorsel, E.; Cleverly, J. Evaluation of the remote-sensing-based DIFFUSE model for estimating photosynthesis of vegetation. Remote Sens. Environ. 2014, 155, 349-365. [CrossRef]

56. Tambussi, E.; Nogues, S.; Ferrio, P.; Voltas, J.; Araus, J. Does higher yield potential improve barley performance in Mediterranean conditions? A case study. Field Crop. Res. 2005, 91, 149-160. [CrossRef]

57. Jensen, C.; Mogensen, V.; Mortensen, G.; Andersen, M.N.; Schjoerring, J.; Thage, J.; Koribidis, J. Leaf photosynthesis and drought adaptation in field-grown oilseed rape (Brassica napus L.). Funct. Plant. Biol. 1996, 23, 631-644. [CrossRef]

58. ABARES. Australian Agricultural Overview; Australian Bureau of Agricultural and Resource Economics and Sciences: Canberra, Australia, 2018; p. 26.

59. Wilson, A.M.; Jetz, W. Remotely sensed high-resolution global cloud dynamics for predicting ecosystem and biodiversity distributions. PLoS Biol. 2016, 14, e1002415. [CrossRef]

60. Jovanovic, B.; Collins, D.; Braganza, K.; Jakob, D.; Jones, D.A. A high-quality monthly total cloud amount dataset for Australia. Clim. Chang. 2011, 108, 485-517. [CrossRef]

61. Portmann, R.W.; Solomon, S.; Hegerl, G.C. Spatial and seasonal patterns in climate change, temperatures, and precipitation across the United States. Proc. Natl. Acad. Sci. USA 2009, 106, 7324-7329. [CrossRef]

62. Ludwig, F.; Milroy, S.P.; Asseng, S. Impacts of recent climate change on wheat production systems in Western Australia. Clim. Chang. 2009, 92, 495-517. [CrossRef]

63. Dreccer, M.F.; Fainges, J.; Whish, J.; Ogbonnaya, F.C.; Sadras, V.O. Comparison of sensitive stages of wheat, barley, canola, chickpea and field pea to temperature and water stress across Australia. Agric. For. Meteorol. 2018, 248, 275-294. [CrossRef]

64. Cai, W.; Cowan, T. Dynamics of late autumn rainfall reduction over southeastern Australia. Geophys. Res. Lett. 2008, 35. [CrossRef]

65. Van Dijk, A.I.; Beck, H.E.; Crosbie, R.S.; de Jeu, R.A.; Liu, Y.Y.; Podger, G.M.; Timbal, B.; Viney, N.R. The millennium drought in southeast Australia (2001-2009): Natural and human causes and implications for water resources, ecosystems, economy, and society. Water Resour. Res. 2013, 49, 1040-1057. [CrossRef]

66. Kiem, A.S.; Johnson, F.; Westra, S.; van Dijk, A.; Evans, J.P.; O’Donnell, A.; Rouillard, A.; Barr, C.; Tyler, J.; Thyer, M. Natural hazards in Australia: Droughts. Clim. Chang. 2016, 139, 37-54. [CrossRef]

67. Norris, J.R.; Allen, R.J.; Evan, A.T.; Zelinka, M.D.; O’Dell, C.W.; Klein, S.A. Evidence for climate change in the satellite cloud record. Nature 2016, 536, 72. [CrossRef]

68. Rosenzweig, C.; Parry, M.L. Potential impact of climate change on world food supply. Nature 1994, 367, 133-138. [CrossRef]

69. Parry, M.L.; Rosenzweig, C.; Iglesias, A.; Livermore, M.; Fischer, G. Effects of climate change on global food production under SRES emissions and socio-economic scenarios. Glob. Environ. Chang. 2004, 14, 53-67. [CrossRef]

70. Doraiswamy, P.; Hatfield, J.; Jackson, T.; Akhmedov, B.; Prueger, J.; Stern, A. Crop condition and yield simulations using Landsat and MODIS. Remote Sens. Environ. 2004, 92, 548-559. [CrossRef]

71. Ferencz, C.; Bognar, P.; Lichtenberger, J.; Hamar, D.; Tarcsai, G.; Timar, G.; Molnar, G.; Pásztor, S.; Steinbach, P.; Szekely, B. Crop yield estimation by satellite remote sensing. Int. J. Remote Sens. 2004, 25, 4113-4149. [CrossRef]

72. Chen, Y.; Donohue, R.J.; McVicar, T.R.; Waldner, F.; Mata, G.; Ota, N.; Houshmandfar, A.; Dayal, K.; Lawes, R.A. Nationwide crop yield estimation based on photosynthesis and meteorological stress indices. Agric. For. Meteorol. 2020, 284, 107872. [CrossRef]

73. Kamir, E.; Waldner, F.; Hochman, Z. Estimating wheat yields in Australia using climate records, satellite image time series and machine learning methods. ISPRS J. Photogramm. Remote Sens. 2020, 160, 124-135. [CrossRef]

74. Battude, M.; Al Bitar, A.; Morin, D.; Cros, J.; Huc, M.; Sicre, C.M.; Le Dantec, V.; Demarez, V. Estimating maize biomass and yield over large areas using high spatial and temporal resolution Sentinel-2 like remote sensing data. Remote Sens. Environ. 2016, 184, 668-681. [CrossRef]

75. Skakun, S.; Vermote, E.; Roger, J.-C.; Franch, B. Combined use of Landsat-8 and Sentinel-2A images for winter crop mapping and winter wheat yield assessment at regional scale. AIMS Geosci. 2017, 3, 163. [CrossRef] 
76. Skakun, S.; Vermote, E.; Franch, B.; Roger, J.-C.; Kussul, N.; Ju, J.; Masek, J. Winter Wheat Yield Assessment from Landsat 8 and Sentinel-2 Data: Incorporating Surface Reflectance, Through Phenological Fitting, into Regression Yield Models. Remote Sens. 2019, 11, 1768. [CrossRef]

77. Betbeder, J.; Fieuzal, R.; Baup, F. Assimilation of LAI and dry biomass data from optical and SAR images into an agro-meteorological model to estimate soybean yield. IEEE J. Sel. Top. Appl. Earth Obs. Remote Sens. 2016, 9, 2540-2553. [CrossRef]

78. Patel, P.; Srivastava, H.S.; Navalgund, R.R. Estimating wheat yield: An approach for estimating number of grains using cross-polarised ENVISAT-1 ASAR data. In Proceedings of the Microwave Remote Sensing of the Atmosphere and Environment V, Goa, India, 13-17 November 2006; p. 641009.

79. Eitel, J.U.; Magney, T.S.; Vierling, L.A.; Brown, T.T.; Huggins, D.R. LiDAR based biomass and crop nitrogen estimates for rapid, non-destructive assessment of wheat nitrogen status. Field Crop. Res. 2014, 159, 21-32. [CrossRef]

80. Joshi, N.; Baumann, M.; Ehammer, A.; Fensholt, R.; Grogan, K.; Hostert, P.; Jepsen, M.; Kuemmerle, T.; Meyfroidt, P.; Mitchard, E. A review of the application of optical and radar remote sensing data fusion to land use mapping and monitoring. Remote Sens. 2016, 8, 70. [CrossRef]

(C) 2020 by the authors. Licensee MDPI, Basel, Switzerland. This article is an open access article distributed under the terms and conditions of the Creative Commons Attribution (CC BY) license (http://creativecommons.org/licenses/by/4.0/). 